\title{
Antigenotoxic and Apoptotic Activity of Green Tea Polyphenol Extracts on Hexavalent Chromium-Induced DNA Damage in Peripheral Blood of CD-1 Mice: Analysis with Differential Acridine Orange/Ethidium Bromide Staining
}

\author{
María del Carmen García-Rodríguez, Megumi Monserrat Carvente-Juárez, \\ and Mario Agustín Altamirano-Lozano \\ Unidad de Investigación en Genética y Toxicología Ambiental (UNIGEN), Facultad de Estudios Superiores "Zaragoza”, \\ Universidad Nacional Autónoma de México (UNAM), Batalla 5 de Mayo s/n, 09230, DF, Mexico
}

Correspondence should be addressed to María del Carmen García-Rodríguez; carmen.garcia@unam.mx

Received 5 August 2013; Revised 29 October 2013; Accepted 30 October 2013

Academic Editor: David Vauzour

Copyright (c) 2013 María del Carmen García-Rodríguez et al. This is an open access article distributed under the Creative Commons Attribution License, which permits unrestricted use, distribution, and reproduction in any medium, provided the original work is properly cited.

\begin{abstract}
This study was conducted to investigate the modulating effects of green tea polyphenols on genotoxic damage and apoptotic activity induced by hexavalent chromium [Cr (VI)] in CD-1 mice. Animals were divided into the following groups: (i) injected with vehicle; (ii) treated with green tea polyphenols $(30 \mathrm{mg} / \mathrm{kg})$ via gavage; (iii) injected with $\mathrm{CrO}_{3}(20 \mathrm{mg} / \mathrm{kg})$ intraperitoneally; (iv) treated with green tea polyphenols in addition to $\mathrm{CrO}_{3}$. Genotoxic damage was evaluated by examining micronucleated polychromatic erythrocytes (MN-PCEs) obtained from peripheral blood at $0,24,48$, and $72 \mathrm{~h}$ after treatment. Induction of apoptosis and cell viability were assessed by differential acridine orange/ethidium bromide (AO/EB) staining. Treatment of green tea polyphenols led to no significant changes in the MN-PCEs. However, $\mathrm{CrO}_{3}$ treatment significantly increased MN-PCEs at 24 and $48 \mathrm{~h}$ after injection. Green tea polyphenols treatment prior to $\mathrm{CrO}_{3}$ injection led to a decrease in MN-PCEs compared to the group treated with $\mathrm{CrO}_{3}$ only. The average of apoptotic cells was increased at $48 \mathrm{~h}$ after treatment compared to control mice, suggesting that apoptosis could contribute to eliminate the DNA damaged cells induced by $\mathrm{Cr}$ (VI). Our findings support the proposed protective effects of green tea polyphenols against the genotoxic damage induced by $\mathrm{Cr}$ (VI).
\end{abstract}

\section{Introduction}

Green tea (Camellia sinensis) is one of the most ancient beverages, consumed by over two-thirds of the world's population. The principal constituents are caffeine, tannins, and essential oils. The tannins encompass a variety of polyphenolic compounds, including important flavonoids such as catechins: (-)-epicatechin (EC), (-)-epigallocatechin (EGC) and their gallate forms (+) gallocatechin (GC), (-) epicatechin-3gallate (ECG) and (-) epigallocatechin-3-gallate (EGCG) $[1,2]$. These compounds are chemically classified as dibenzpyrans, pyrones, and their derivatives. The core structure contains a diphenylpropane skeleton (Figure 1(a)). The primary flavonoids found in fresh green tea leaves are catechins (flavan-3-ols or flavanols) and the flavonols (Figures 1(b) and 1(c), resp.) [1]. In addition, green tea contains other polyphenols such as theaflavins (Figure 1(d)) but at lower concentration than catechins. The polyphenols are also naturally found in fruits and vegetables, as well as in drinks such as red wine and beer $[1,2]$.

Green tea has attracted significant attention recently, both in the scientific and in consumer communities for its health benefits for a variety of diseases associated with oxidative stress such as cancer, cardiovascular, and neurodegenerative diseases $[3,4]$. The beneficial effects of green tea are attributed to the antioxidant properties of the polyphenolic compounds. In addition to the cancer chemopreventive properties, green 
<smiles>c1ccc(C2CCc3ccccc3O2)cc1</smiles>

(a)

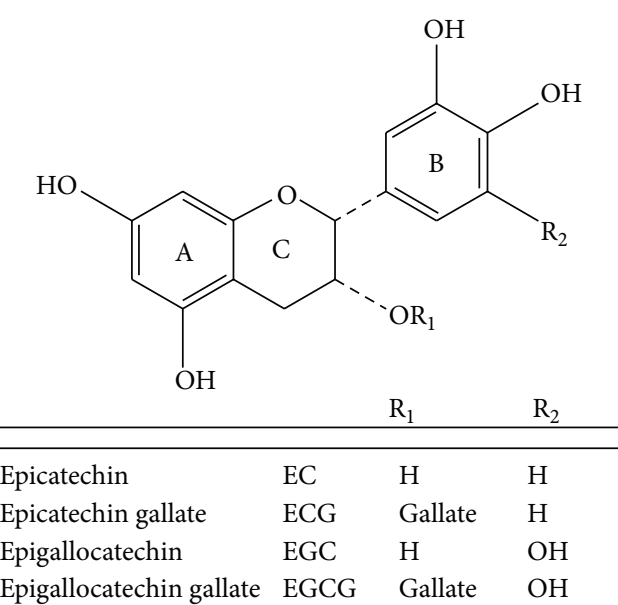

(b)

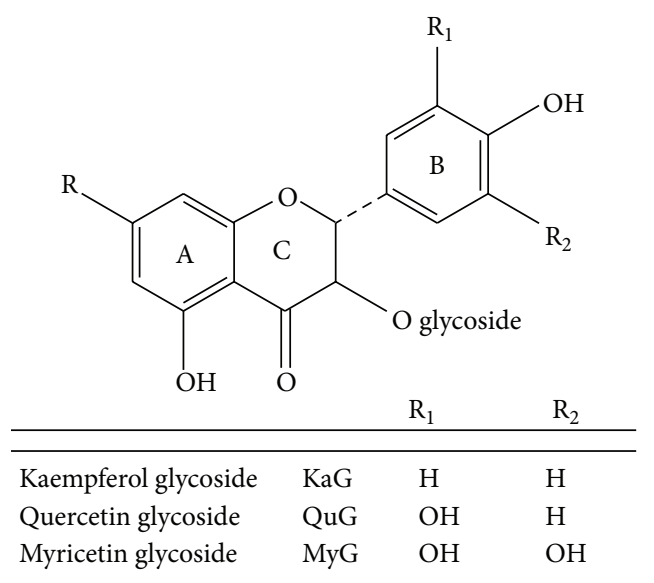

(c)

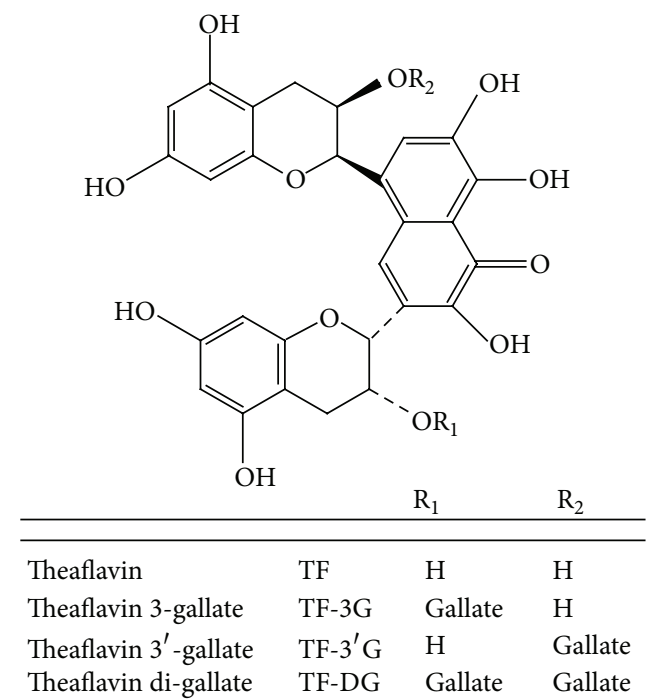

(d)

FIGURE 1: Classification of flavonoids. (a) Flavonoid diphenylpropane skeleton; (b) tea flavanols (flavan-3-ols); (c) tea flavonols; (d) tea theaflavins.

tea polyphenols have shown anti-inflammatory, antiallergenic, antibacterial, and antiviral properties [4-6], as well as antimutagenic activity [7].

The polyphenol compounds have shown direct effects as radical scavengers and metal chelators and indirect effects via the modulation of transcription factors and enzymes $[8,9]$. In fact, these antioxidants can inhibit the formation of 8-hydroxydeoxyguanosine (8-OH-dG, 7,8-dihydro-8oxodeoxyguanosine) in vivo $[10,11]$. Thus, substances with antioxidant properties have emerged as putative preventives and coadjuvants in the treatment of chronic degenerative diseases related to oxidative stress and DNA damage.

In contrast, hexavalent chromium [Cr (VI)] compounds are particularly effective at inducing genotoxicity by causing several types of DNA lesions and gene mutations. Cr (VI) compounds have been widely studied because they have various industrial applications, including chromium plating, metallurgy, pigment manufacturing, leather tanning, and wood preservation, and because they are associated with the induction of cancer [12]. Cr usually exists in various oxidation states, primarily $\mathrm{Cr}$ (III) and Cr (VI). Nonetheless, $\mathrm{Cr}$ (III) is an essential micronutrient and plays an important role in protein, sugar, and fat metabolism [13]. Cr (VI) is particularly effective at inducing genotoxicity by causing several types of DNA lesions and gene mutations. Cr (VI)induced DNA-DNA interstrand cross-links, oxidative DNA damage, and mutations in the tumor suppressor gene p53 are some of the major factors that may play a significant role in determining cellular genotoxicity [14, 15]. According to previous studies, Cr-induced genomic DNA damage includes 8-hydroxydeoxyguanosine ( $8-\mathrm{OH}$-dG, 7,8-dihydro8-oxodeoxyguanosine), which is a form of oxidative DNA damage [16]. Maeng et al. [17] observed changes in 8-OH$\mathrm{dG}$ levels in DNA when rats were exposed to $\mathrm{Cr}(\mathrm{VI})$ and 
suggest that DNA damage caused by $\mathrm{Cr}(\mathrm{VI})$ compounds may be partially associated with oxidative stress. $\mathrm{Cr}(\mathrm{VI})$ generates reactive oxygen species (ROS) and free radicals (FRs) via its intracellular reduction to $\mathrm{Cr}$ (III) via the Fenton and HaberWeiss reaction $[15,18,19]$. Although the direct relationship between DNA-ROS and chromium-induced DNA damage is heavily debated and unclear, there have been several studies supporting the role of ROS in $\mathrm{Cr}$ (VI)-induced genotoxicity and cytotoxicity [20]. Moreover, it has been observed that $\mathrm{Cr}$ (VI) given orally to mice could induce dose- and timedependent effects on hepatic oxidative stress and hepatocyte apoptosis [21]. Apoptosis is a process in which cell death is initiated and completed in an orderly manner through the activation and/or synthesis of gene products necessary for cell destruction [22]. Apoptosis plays a crucial role in a number of physiological and pathological processes and is accompanied by characteristic morphological changes, which include cytoplasmic shrinkage, plasma membrane blebbing, condensation or fragmentation of nuclei, and extensive degradation of chromosomal DNA. Indeed, many chemopreventive agents act by inducing apoptosis as a mechanism to suppress carcinogenesis [23]. Roy et al. [24] observed that EGCG not only protects normal cells against genotoxic alterations induced by MNNG but also eliminates cancer cells via the induction of apoptosis in vitro. We previously observed that in vivo administration of green tea (ad libitum for 10 days) decreased the induction of MN-PCEs upon treatment with $\mathrm{CrO}_{3}$. This result supports the protective effects of green tea against the genotoxic damage induced by metal compounds such as $\mathrm{Cr}$ (VI). However, the MN-PCEs induced by $\mathrm{CrO}_{3}$ were only partially blocked by the addition of green tea (approximately 42\%) at days 1 and 2 [25]. This finding may be related to factors such as the origin of the tea because it has been observed that the amount of polyphenols in tea plants is influenced by environmental factors (i.e., weather, light, nutrients, preparation process, storage, horticulture leaf age, etc.). Also, it has been reported that polyphenols make up more than $30 \%$ of the dry weight of tea leaves; $90 \%$ of these compounds are catechins, and $10 \%$ are flavonols [2628]. Therefore, as part of our research program that evaluates chemopreventive and chemoprotective components in the diet, to obtain a more efficient modulation of the genotoxic damage induced by $\mathrm{Cr}$ (VI) in vivo, we directly studied green tea polyphenol extracts that contain a mixture of polyphenolic compounds (minimum 60\% total catechins with higher antioxidant activity [Polyphenon 60]), and we analyzed its apoptotic activity in the peripheral blood of CD-1 mice using analysis with differential acridine orange/ethidium bromide staining.

\section{Materials and Methods}

2.1. Chemicals. The following test chemicals and reagents were obtained from Sigma Chemicals Co. (St. Louis, MO, USA): $\mathrm{CrO}_{3}$ [CAS no. 1333-82-0], acridine orange (AO) [CAS no. 10127-02-3], ethidium bromide (EB) [CAS no. 1239-45-8], and green tea polyphenol extracts (Polyphenon 60) [CAS no. 138988-88-2].
2.2. Animals. Two- to three-month-old CD-1 male mice (28$35 \mathrm{~g}$ ) were used in the experiments. The animals were kept under controlled temperature $\left(22^{\circ} \mathrm{C}\right)$ with a $12-12 \mathrm{~h}$ light-dark period (light 07:00-19:00 h). Mice had free access to food (Purina-México chow for small rodents) and water. All of the mice were obtained from Harlan at "Facultad de Química, Universidad Nacional Autónoma de México" (UNAM) and were acclimated for a two-week period. The Bioethics Committee of the "Facultad de Estudios Superiores-Zaragoza", UNAM approved the experimental protocols used in this study.

2.3. Experimental Design. The dosage of green tea polyphenols extract (Polyphenon 60) was based on results obtained in previous studies, which utilized other commercially available Polyphenon 60 (0.625-1.25\% body weight) [29] and our preliminary studies to determine the maximum tolerated dose (MTD) that did not induce MN-PCEs. The $\mathrm{CrO}_{3}$ dose was selected according to previous studies that intraperitoneally (i.p.) administered $20 \mathrm{mg} / \mathrm{kg}$. This $\mathrm{CrO}_{3}$ dosage induced $\mathrm{MN}$ PCEs in the peripheral blood of mice [30].

The green tea polyphenol extracts and $\mathrm{CrO}_{3}$ were prepared in solution by dissolving the dry compounds in sterile distilled water. Following preparation of the compounds, the solutions $(0.25 \mathrm{~mL})$ were administered immediately. The control group was treated in an identical manner with vehicle only. The evaluation criteria and work conditions were set up according to the OECD guideline (474), Food and Drug Administration (FDA) guidelines, Environmental Protection Agency (EPA) guidelines, and guidelines for the testing of chemicals specified by the Collaborative Study Group for the Micronucleus Test (CSGMT) and the Mammalian Mutagenesis Study Group of the Environmental Society of Japan (JEMS.MMS) for the short-term mouse peripheral blood micronucleus test [31-35].

After establishing treatment doses, the effects of green tea polyphenol extracts on genotoxic damage in $\mathrm{CrO}_{3}$ treated mice were evaluated. This assessment was performed using MN-PCEs kinetic analysis [31]. Mice were assigned at random to one of the following groups $(n=5$ mice per group).

(1) Animals injected with vehicle (control group).

(2) Animals treated with green tea polyphenol extract $(30 \mathrm{mg} / \mathrm{kg})$ by gavage.

(3) Animals injected with $\mathrm{CrO}_{3}(20 \mathrm{mg} / \mathrm{kg})$.

(4) Animals treated with green tea polyphenol extract $(30 \mathrm{mg} / \mathrm{kg})$ by gavage and then ( $4 \mathrm{~h}$ later) injected with $\mathrm{CrO}_{3}(20 \mathrm{mg} / \mathrm{kg})$.

2.4. Micronucleus Assay. Slides were covered with AO and prepared according to the technique described by Hayashi et al. [36]. Briefly, AO was dissolved in distilled water at a concentration of $1 \mathrm{mg} / \mathrm{mL}$, and $10 \mu \mathrm{L}$ of this solution was placed on a preheated (approximately $70^{\circ} \mathrm{C}$ ) clean glass slide. The AO was spread evenly on the slide by moving a glass rod back and forth over the slide, which was then air-dried. 


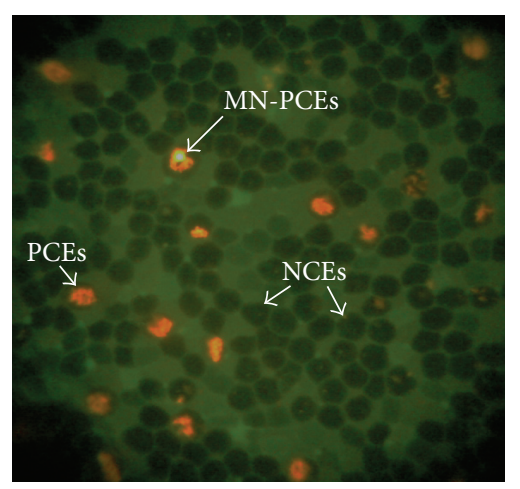

(a)
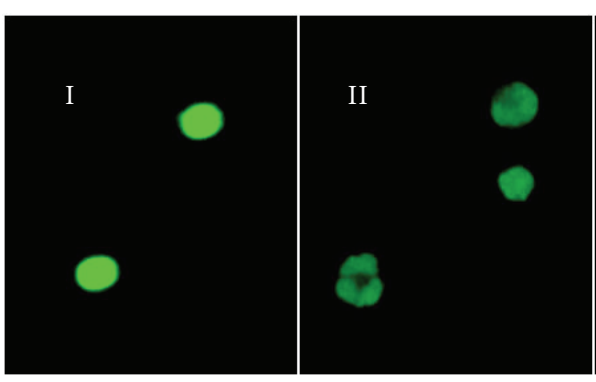

(b)
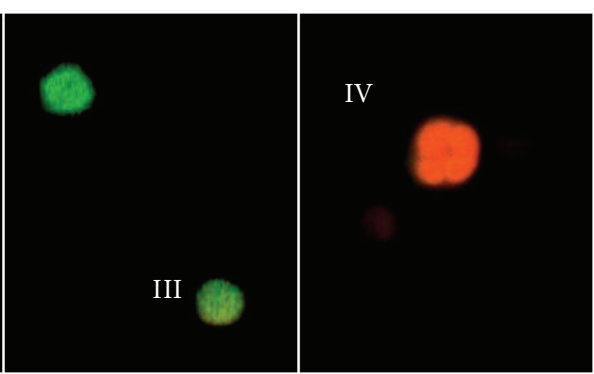

FIgURE 2: (a) Fluorescent microphotograph of CD-1 mouse peripheral blood cells using the AO coating method (NCEs, PCEs, and MNPCEs). (b) Morphology of viable cells (apoptotic and nonapoptotic cells) and nonviable cells (apoptotic and nonapoptotic cells) as assessed by acridine orange/ethidium bromide staining. Viable cells stain uniformly green (I), early apoptotic cells with intact plasma membranes appear green, with "dots" of condensed chromatin that are highly visible within (II), late apoptotic cells are stained bright green-orange because membrane blebbing starts to occur, EB can enter the cell (III), and apoptotic nonviable cells are stained bright orange because of the entry of ethidium bromide into these cells (VI).

The AO-coated glass slides were stored in a dark, dry location at room temperature prior to experimental use.

To evaluate $\mathrm{MN}$ after treatment, $5 \mu \mathrm{L}$ peripheral blood samples were collected by piercing a tail blood vessel of the mice every $24 \mathrm{~h}$ during a four-day period $(0$ to $72 \mathrm{~h}$ ). The samples were placed directly on slides previously treated with $\mathrm{AO}$ according to Hayashi et al. [36]. After the sample was placed on the slide, a coverslip $(24 \times 50 \mathrm{~mm})$ was immediately placed on the slide, and its edges were sealed with rubber cement. All of the slide preparations were kept in plastic boxes in the dark at $4^{\circ} \mathrm{C}$. These slide preparations cannot be stored permanently, but they can be stored for several days in a refrigerator if the coverslip has been sealed. Two slides were prepared for each mouse, and analysis of the slides was conducted after $12 \mathrm{~h}$.

PCEs, NCEs, and MN-PCEs were identified under a fluorescent microscope (Nikon OPTIPHOT-2) using a blue excitation filter and a yellow barrier filter. The differential AO staining distinguished PCEs from NCEs, as PCEs were stained a fluorescent red-orange color due to the presence of ribosomal RNA. The AO staining also identified MN-PCEs, which were stained a fluorescent green color due to their DNA content (Figure 2(a)). The MN-PCEs analysis was based on the results from 2,000 cells per mouse, and the presence of MN-PCEs was used as a marker for genotoxic damage [36].

2.5. Apoptosis and Cell Viability Analyses. To evaluate apoptosis and cell viability we used the differential acridine orange/ethidium bromide (AO/EB) staining. Blood samples $(100 \mu \mathrm{L})$ were collected by piercing a tail blood vessel of the mice prior to treatment and $48 \mathrm{~h}$ after treatment. Heparin $(10 \mu \mathrm{L})$ was added to the blood samples, and $20 \mu \mathrm{L}$ of $\mathrm{AO} / \mathrm{EB}$ dye mix $(100 \mu \mathrm{L} / \mathrm{mL} \mathrm{AO}$ and $100 \mu \mathrm{L} / \mathrm{mL}$ EB, both prepared in PBS) was then added. The suspension was concentrated via centrifugation $(5,000 \mathrm{rpm})$, and the cell pellet was resuspended in $10 \mu \mathrm{L}$ and plated on a clean slide; a coverslip $(24 \times 24 \mathrm{~mm})$ was immediately placed on the slide. Two slides were prepared per mouse, and the analysis was conducted immediately.

Apoptosis was assessed by identifying apoptotic, viable and nonviable cells under a fluorescent microscope (Nikon OPTIPHOT-2) with a blue excitation $(480 \mathrm{~nm})$ and a barrier filter $(515-530 \mathrm{~nm})$. The differential AO/EB staining is capable of distinguishing between viable and nonviable cells based on membrane integrity. When the cell is viable, the AO intercalates into the DNA, giving the cell a green appearance. Conversely, when the cell is nonviable, the $\mathrm{EB}$ also intercalates into the DNA, making the cell appear orange. Thus, a nonviable cell will contain a bright orange nucleus as EB overwhelms AO staining. Both healthy and apoptotic nuclei in viable cells will fluoresce bright green. In contrast, healthy or apoptotic nuclei in nonviable cells will fluoresce bright orange [33]. The apoptotic and cell viability assessments were based on 200 cells per mouse.

2.6. Statistical Analysis. The MN-PCEs induction results and the viable cells (apoptotic and nonapoptotic) and nonviable cells (apoptotic and nonapoptotic) data are expressed as the mean \pm standard deviation (S.D.), and results from the various treatment groups were compared by an ANOVA test followed by a Tukey test. The net induction frequency (NIF) of MN-PCEs was analyzed using a Chi-square test $[30,37]$. SPSS/PC V18TM and Statistica/PC V 6.0TM software were used for the statistical analyses. For all of the analyses, $P<$ 0.05 was considered to be significant.

\section{Results}

The results obtained in the present study are shown in Table 1. Vehicle and green tea polyphenol extract did not modify the average number of induced MN-PCEs in the treated mice. $\mathrm{CrO}_{3}$ treatment increased the average number of MN-PCEs in all of the samples, but statistical significance was only 
TABLE 1: Averages of the induction MN-PCEs in peripheral blood of mice treated with polyphenol extracts of green tea and $\mathrm{CrO}_{3}$.

\begin{tabular}{|c|c|c|c|c|c|}
\hline Treatment & Dose $(\mathrm{mg} / \mathrm{kg})$ & $n$ & Time analysis (hours) & MN-PCEs 2,000 cells (mean \pm S.D.) & $\overline{\text { ANOVA }}$ \\
\hline \multirow{4}{*}{ Control } & \multirow{4}{*}{0} & \multirow{4}{*}{5} & 0 & $0.6 \pm 0.9$ & \\
\hline & & & 24 & $0.8 \pm 0.8$ & \\
\hline & & & 48 & $1.2 \pm 0.8$ & \\
\hline & & & 72 & $1.6 \pm 1.5$ & \\
\hline \multirow{4}{*}{ Polyphenol extracts of green tea } & \multirow{4}{*}{30} & \multirow{4}{*}{5} & 0 & $1.0 \pm 1.2$ & \\
\hline & & & 24 & $1.8 \pm 1.9$ & \\
\hline & & & 48 & $1.2 \pm 1.3$ & \\
\hline & & & 72 & $1.4 \pm 0.5$ & \\
\hline \multirow{4}{*}{$\mathrm{CrO}_{3}$} & \multirow{4}{*}{20} & \multirow{4}{*}{5} & 0 & $0.2 \pm 0.5$ & \multirow{4}{*}{$a, b, c, d$} \\
\hline & & & 24 & $3.0 \pm 1.6$ & \\
\hline & & & 48 & $13.2 \pm 3.8$ & \\
\hline & & & 72 & $3.4 \pm 1.1$ & \\
\hline \multirow{4}{*}{ Polyphenol extracts of green tea- $\mathrm{CrO}_{3}$} & \multirow{4}{*}{$30-20$} & \multirow{4}{*}{5} & 0 & $1.2 \pm 1.3$ & \multirow{4}{*}{$a, b, e$} \\
\hline & & & 24 & $0.6 \pm 0.5$ & \\
\hline & & & 48 & $5.2 \pm 1.8$ & \\
\hline & & & 72 & $1.2 \pm 1.1$ & \\
\hline
\end{tabular}

observed at the $48 \mathrm{~h}$ time point when compared to the $0 \mathrm{~h}$ samples and the control group. Furthermore, $\mathrm{CrO}_{3}$ treatment increased the average number of MN-PCEs (approximately 13 MN-PCEs) compared to vehicle-treated mice. When the treatment included both green tea polyphenol extract and $\mathrm{CrO}_{3}$, we observed a decrease in the average number of $\mathrm{MN}$ PCEs at 24, 48, and $72 \mathrm{~h}$ after treatment when compared to MN-PCEs induction in the $\mathrm{CrO}_{3}$ only treatment group, but the MN-PCEs induction observed at 48 remains statistically significant compared with the control group (Table 1). To compare the kinetics of MN-PCE induction in the various treatment groups, the data were analyzed by calculating the NIF value, which was calculated as follows [30]:

$$
\begin{aligned}
\text { NIF }= & \text { number of MN-PCEs measured at time } x_{i} \\
& - \text { number of MN-PCEs measured at time } 0 \text {, }
\end{aligned}
$$

where $x_{i}=$ evaluation at 24,48 , or $72 \mathrm{~h}$. Time $0=$ evaluation at $0 \mathrm{~h}$ (before treatment).

When the NIF is calculated, the net MN-PCEs induction can be more readily observed. This calculation subtracts the frequency of MN-PCEs prior to treatment from the frequency following treatment, thereby eliminating the baseline MN-PCEs variability that occurs between the treatment groups at time 0 (see S.D. Table 1). Figure 3 presents the NIF values for all treatments at 24,48 , and $72 \mathrm{~h}$ after treatment. The groups treated with green tea polyphenol flavonoid extracts exhibited a principal MN-PCEs reduction at 24 and $72 \mathrm{~h}$ after treatment (approximately $121 \%$ and $100 \%$, resp.).

Apoptosis and cell viability were evaluated directly in the peripheral blood of mice before $(0 \mathrm{~h})$ and after $(48 \mathrm{~h})$ treatment. Induction of apoptosis and cell viability were assessed via $\mathrm{AO} / \mathrm{EB}$ staining of peripheral blood collected from treated mice. This technique shows the differential uptake of the fluorescent DNA-binding dyes AO and EB to determine viable and nonviable cells. These dyes were used to identify cells that have undergone apoptosis and to distinguish between cells in the early or late stages of apoptosis based on membrane integrity (Figure 2(b)). AO intercalates into the DNA, giving it a green appearance. This dye also binds to RNA, but because it cannot intercalate, the RNA stains red orange. Thus, a viable cell will have a bright green appearance. EB is only taken up by nonviable cells. This dye also intercalates into DNA, making it appear orange; however, EB only binds weakly to RNA, which may appear slightly red. Thus, a nonviable cell will have a bright orange nucleus, as EB overwhelms AO staining, and its cytoplasm will appear dark red (if any content remains). Both normal and apoptotic nuclei in viable cells will fluoresce bright green (Figure 2(b), I-III). In contrast, normal or apoptotic nuclei in nonviable cells will fluoresce bright orange (Figure 2(b), IV). Therefore, one can differentiate between early and late apoptotic cells using this system. Viable cells with intact membranes will have a uniformly stained green nucleus (Figure 2(b), I). Early apoptotic cells with intact membranes but that have started to fragment their DNA will still have green nuclei because EB cannot enter the cell, but chromatin condensation can be visualized as bright green patches in the nuclei (Figure 2(b), II). As the cell progresses through the apoptotic pathway and membrane blebbing starts to occur, $\mathrm{EB}$ can enter the cell, causing the cell to stain green orange (Figure 2, III). Late apoptotic cells will have bright orange patches of condensed chromatin in the nucleus that will distinguish these cells from necrotic cells, which will be uniformly stained orange (Figure 2, IV).

All of the treatments increased the average number of apoptotic viable cells, but statistical significance was achieved only in the $\mathrm{CrO}_{3}$ treatment group and the combined green 


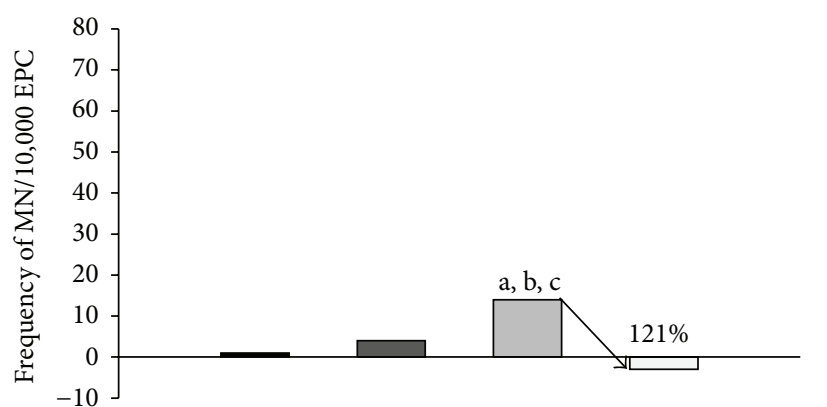

(a)

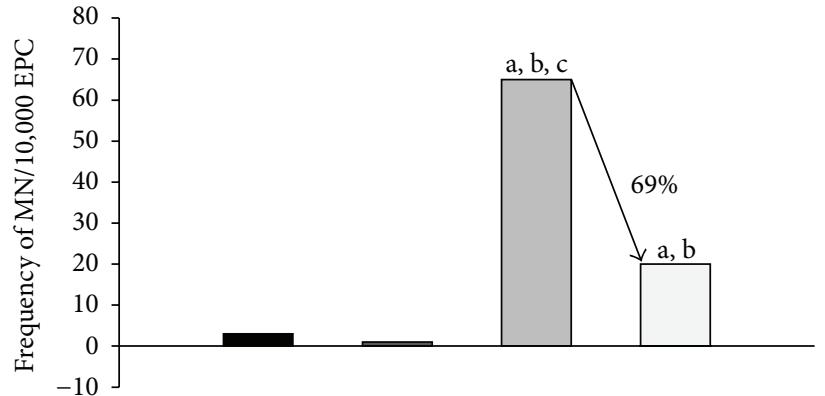

(b)

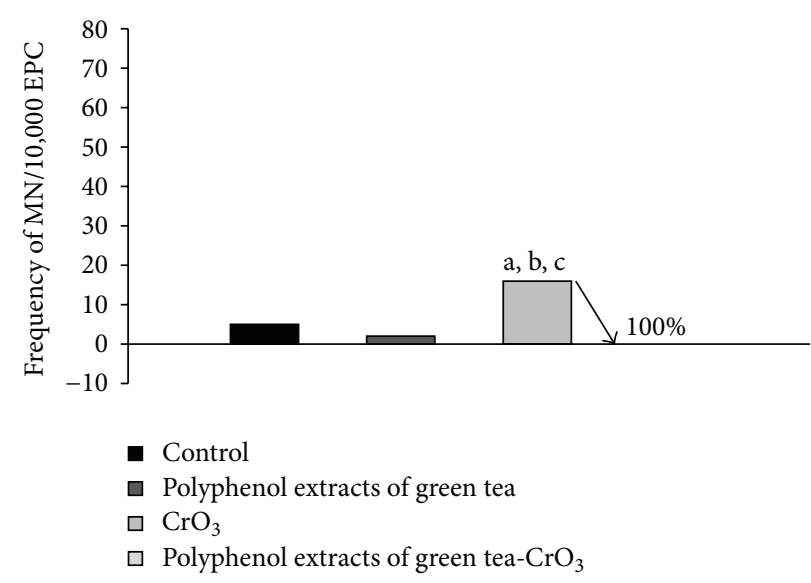

(c)

FIGURE 3: Effects of polyphenol extracts of green tea on the MN-PCEs frequency (\% reduction) in mice peripheral blood at different times: (a) $24 \mathrm{~h}$, (b) $48 \mathrm{~h}$, and (c) $72 \mathrm{~h}$ after treatment with $\mathrm{CrO}_{3}$. Data represent MN-PCEs frequency obtained at 24, 48, and 72 h minus the MNPCEs frequency at $0 \mathrm{~h}$ (NIF). ${ }^{\mathrm{a}} \mathrm{P}<0.05$ versus control group; ${ }^{\mathrm{b}} \mathrm{P}<0.05$ versus polyphenol extracts of green tea group; ${ }^{\mathrm{c}} \mathrm{P}<0.05$ versus $\mathrm{CrO}_{3}$-polyphenol extracts of green tea group. $n=5$ (2000 cells for mouse).

TABLE 2: Averages of viable cells (apoptotic and nonapoptotic) and nonviable cells (apoptotic and nonapoptotic) in peripheral blood of mice treated with polyphenol extract of green tea and $\mathrm{CrO}_{3}$.

\begin{tabular}{|c|c|c|c|c|c|c|}
\hline Treatment & Dose $(\mathrm{mg} / \mathrm{kg})$ & $n$ & $\begin{array}{l}\text { Nonapoptotic viable } \\
\text { cells* }^{*} \text { (mean } \pm \text { S.D.) }\end{array}$ & $\begin{array}{c}\text { Apoptotic viable } \\
\left.\text { cells* }^{*} \text { (mean } \pm \text { S.D. }\right)\end{array}$ & $\begin{array}{l}\text { Apoptotic nonviable } \\
\text { cells }^{*}(\text { mean } \pm \text { S.D.) }\end{array}$ & $\begin{array}{l}\text { Nonapoptotic } \\
\text { nonviable cells } \\
(\text { mean } \pm \text { S.D. })\end{array}$ \\
\hline Control & 0 & 5 & $197.2 \pm 2.2$ & $2.4 \pm 1.8$ & $0.0 \pm 0.0$ & $0.4 \pm 0.9$ \\
\hline $\begin{array}{l}\text { Polyphenol extracts of } \\
\text { green tea }\end{array}$ & 30 & 5 & $192.8 \pm 4.9$ & $6.0 \pm 4.1$ & $0.8 \pm 1.3$ & $0.4 \pm 0.6$ \\
\hline $\mathrm{CrO}_{3}$ & 20 & 5 & $189.2 \pm 3.3^{\mathrm{a}}$ & $10.2 \pm 3.6^{\mathrm{c}}$ & $0.2 \pm 0.5$ & $0.4 \pm 0.6$ \\
\hline $\begin{array}{l}\text { Polyphenol extracts of } \\
\text { green tea- } \mathrm{CrO}_{3}\end{array}$ & $30-20$ & 5 & $187.2 \pm 6.3^{\mathrm{b}}$ & $12.8 \pm 6.3^{\mathrm{d}}$ & $0.0 \pm 0.0$ & $0.0 \pm 0.0$ \\
\hline
\end{tabular}

${ }^{\mathrm{a}} P<0.05$ versus control; ${ }^{\mathrm{b}} P<0.01$ versus control; ${ }^{\mathrm{c}} P<0.04$ versus control; ${ }^{\mathrm{d}} P<0.007$ versus control.

* Evaluation in 200 cells.

tea polyphenol extract- $\mathrm{CrO}_{3}$ group compared to the control group. The increase in apoptosis was greater in the combined green tea polyphenol extract- $\mathrm{CrO}_{3}$ group than in the $\mathrm{CrO}_{3}$ group (12.8 versus 10.2 cells, resp.). The green tea polyphenol extract only treatment group had an increase of approximately four apoptotic viable cells compared to the control group. The average numbers of apoptotic nonviable cells and nonapoptotic cells were unchanged in all of the treatment groups (Table 2).

\section{Discussion}

The antioxidant properties present in polyphenols make them potentially useful for counteracting the DNA damage induced by oxidative stress agents such as $\mathrm{Cr}$ (VI) compounds. In this study, we evaluated the capability of polyphenol extracts from green tea to inhibit the genotoxic damage induced by $\mathrm{Cr}$ (VI) in vivo and analyzed apoptosis in peripheral blood of CD-1 mice. 
The genotoxicity of $\mathrm{Cr}$ (VI) was demonstrated by the observation of a significant increase in MN-PCEs at 24 and $48 \mathrm{~h}$ after treatment in the $\mathrm{CrO}_{3}$-treated group (Table 1). This increase was clearly observed in all samples compared to the negative control, and this finding corroborates the previously reported genotoxicity of $\mathrm{Cr}(\mathrm{VI})$ and particularly $\mathrm{CrO}_{3}[15$, $30,38]$. The mechanism of genotoxicity for $\mathrm{Cr}$ (VI) compounds has been linked to the intracellular reduction of $\mathrm{Cr}$ (VI) to $\mathrm{Cr}$ (III). Cr (VI) compounds can cross cell membranes via nonspecific anion transporters and are reduced by their interaction with intracellular cytoplasmic molecules. During this process, FRs are generated, which are capable of inducing genotoxic alterations $[15,18,19]$. Hence, we suggest that these effects can lead to the formation of MN-PCEs.

However, the average number of MN-PCEs revealed an increase of less than $1 \mathrm{MN}$-PCEs at $24 \mathrm{~h}$ after treatment in the group treated with green tea polyphenol extracts (Table 1), and the calculated NIF value corroborates the nongenotoxic effect of these extracts (Figure 3). It has been reported that the administration of polyphenol or flavonoids from green tea does not induce genotoxicity; additionally, the administration of these compounds over a long period of time at high doses in experimental animals has no effect on genotoxicity $[4,39,40]$.

The in vivo administration of green tea polyphenol extracts prior to $\mathrm{CrO}_{3}$ injection decreased MN-PCEs formation by $121 \%, 69 \%$ and $100 \%$ at 24,48 , and $72 \mathrm{~h}$ after treatment, respectively, compared to $\mathrm{MN}$-PCEs formation in the group treated with $\mathrm{CrO}_{3}$ alone (Figure 3). This result demonstrates that green tea polyphenol extracts protected cells against Cr (VI)-induced genetic damage more effectively than the administration of green tea ad libitum [25]. Due to the phenolic structure of green tea polyphenol extracts (Figure 1), it is possible that these flavonoids may act as hydrogen donors to suppress the formation of lipid radicals and FRs, including the superoxide and hydroxyl radicals generated by the Fenton reaction. These flavonoids may also chelate metals via their ortho-hydroxy-phenolic groups [41, 42]. Therefore, therapeutic agents that enhance intra- and extracellular antioxidant levels and block the Cr (VI)-mediated generation of ROS and FRs may prevent or attenuate Cr (VI)-induced genotoxicity.

In our experiments, the average number of apoptotic viable cells was increased at $48 \mathrm{~h}$ after treatment (Table 2). This increase was observed in all treatment groups compared to the negative control, and this finding supports the previously reported observations following Cr (VI) treatment [4345]. The alteration of intracellular oxidative states has a potential to trigger or sensitize a cell to undergo apoptosis; thus, the ROS generated from Cr (VI) during its reduction plays an important role in the apoptotic signaling pathway $[45,46]$. The administration of green tea polyphenol extracts alone led to an increase in the average number of apoptotic viable cells (approximately 4), but this increase was not statistically significant. Other studies have shown that green tea polyphenols such as EGCG and ECG inhibit the growth of the human lung cancer (cell line PC-9) [47]. The study further demonstrated that growth inhibition was accompanied by cell cycle arrest at the $\mathrm{G} 2 / \mathrm{M}$ phase [48], which could be related to the apoptotic activity of these polyphenols. The induction of apoptosis by catechins has also been demonstrated in human lymphoid leukemia cells, human epidermoid carcinoma cells, human carcinoma keratinocytes, and human prostrate carcinoma cells $[3,49,50]$; thus, apoptosis plays an essential role as a protective mechanism against carcinogenesis by eliminating genetically damaged cells.

When the green tea polyphenol extracts were administered prior to the injection of $\mathrm{CrO}_{3}$, the average number of apoptotic viable cells was increased to a level that was higher than that observed following $\mathrm{CrO}_{3}$ treatment alone, but these interactions have shown that the effects are not additive or antagonistic (Table 2). Gao et al. [51] observed that ascorbic acid could enhance the EGCG and theaflavin-3-30digallate induced apoptosis in human lung adenocarcinoma SPC-A-1 cells and esophageal carcinoma Eca-109 cells. Other studies have shown that the apoptosis-inducing activity of EGCG in human lung adenocarcinoma (PC-9 cells) can be synergistically enhanced by combined treatment with chemopreventive agents (including sulindac, cisplatin, and tamoxifen) $[3,52,53]$. The enhanced induction of apoptosis following a combined treatment suggests that this process may contribute to eliminate the cells with damaged DNA induced by $\mathrm{Cr}$ (VI).

In summary, the current study demonstrates that administration of $\mathrm{CrO}_{3}$ via i.p. injection of mice could induce DNA damage in peripheral blood and apoptosis, and these effects were time dependent. ROS and FRs formation may play an essential role in Cr (VI)-mediated DNA damage and apoptosis in vivo. Moreover, the polyphenol extracts derived from green tea are capable of reducing genotoxic damage induced by $\mathrm{Cr}$ (VI). The greatest degree of protection was observed at $24 \mathrm{~h}$ after injection of $\mathrm{CrO}_{3}$. The magnitude of protection is given in the following order: $121 \%$ at $24 \mathrm{~h},>69 \%$ at $48 \mathrm{~h}$, and $>100 \%$ at $72 \mathrm{~h}$ after injection. Based on these results, polyphenol extracts from green tea can effectively protect against genotoxic damage in mice treated with $\mathrm{Cr}$ (VI). The beneficial effects of green tea polyphenol extracts could result from the inhibition of ROS and FRs chain reactions generated by the oxidative stress caused by $\mathrm{Cr}$ (VI) and by the extract's apoptotic activity.

There is limited evidence demonstrating that the regular consumption of green tea may reduce genotoxic damage. Therefore, this study contributes in vivo evidence showing that green tea polyphenol extracts can protect against genotoxic damage induced by carcinogens related to oxidative stress, such as Cr (VI) compounds.

\section{Abbreviations}

AO: Acridine orange

Cr (VI): Hexavalent chromium

EB: $\quad$ Ethidium bromide

EC: Epicatechin

ECG: Epicatechin-3-gallate

EGC: Epigallocatechin

EGCG: (-)-epigallocatechin-3-gallate

FDA: Food and Drug Administration

FRs: Free radicals 


$\begin{array}{ll}\text { GC: } & (+) \text { gallocatechin } \\ \text { i.p.: } & \text { Intraperitoneal } \\ \text { MNNG: } & \text { N-methyl-N'-nitro-N-nitrosoguanidine } \\ \text { MN-PCEs: } & \text { Micronucleated polychromatic } \\ & \text { erythrocytes } \\ \text { NCEs: } & \text { Normochromatic erythrocytes } \\ \text { NIF: } & \text { Net induction frequency } \\ \text { PCEs: } & \text { Polychromatic erythrocytes } \\ \text { ROS: } & \text { Reactive oxygen species. }\end{array}$

\section{Conflict of Interests}

The authors of the paper declare that they have no direct financial relationship with the commercial identities mentioned in the present paper that might lead to a conflict of interests.

\section{Acknowledgments}

The authors wish to thank Alejandro Gordillo Martínez for his considerable help in the preparation of this paper and Lourdes Hernández Sánchez for her excellent technical assistance. Financial support was obtained from DGAPAUNAM IN217712.

\section{References}

[1] E. Cadenas and L. Packer, Handbook of Antioxidants, Dekker, New York, NY, USA, 2 edition, 2002.

[2] H. Sakakibara, Y. Honda, S. Nakagawa, H. Ashida, and K. Kanazawa, "Simultaneous determination of all polyphenols in vegetables, fruits, and teas," Journal of Agricultural and Food Chemistry, vol. 51, no. 3, pp. 571-581, 2003.

[3] M. Roy, M. Siddiqi, and R. K. Bhattacharya, "Cancer chemoprevention: tea polyphenols induced cellular and molecular responses," Asian Pacific Journal of Cancer Prevention, vol. 2, pp. 109-116, 2001.

[4] N. T. Zaveri, "Green tea and its polyphenolic catechins: medicinal uses in cancer and noncancer applications," Life Sciences, vol. 78, no. 18, pp. 2073-2080, 2006.

[5] C. Braicu, M. R. Ladomery, V. S. Chedea, A. Irimie, and I. Berindan-Neagoe, "The relationship between the structure and biological actions of green tea catechins," Food Chemistry, vol. 141, pp. 3282-3289, 2013.

[6] S. Ellinger, N. Müller, P. Stehle, and G. Ulrich-Merzenich, "Consumption of green tea or green tea products: is there an evidence for antioxidant effects from controlled interventional studies?” Phytomedicine, vol. 18, no. 11, pp. 903-915, 2011.

[7] Y. Kuroda and Y. Hara, "Antimutagenic and anticarcinogenic activity of tea polyphenols," Mutation Research, vol. 436, no. 1, pp. 69-97, 1999.

[8] C. Cabrera, R. Artacho, and R. Giménez, "Beneficial effects of green tea-a review," Journal of the American College of Nutrition, vol. 25, no. 2, pp. 79-99, 2006.

[9] A. A. Khalaf, W. A. Moselhy, and M. I. Abdel-Hamed, "The protective effect of green tea extract on lead induced oxidative and DNA damage on rat brain," NeuroToxicology, vol. 33, no. 3, pp. 280-289, 2012.
[10] M. Inagake, T. Yamane, Y. Kitao et al., "Inhibition of 1,2dimethylhydrazine-induced oxidative DNA damage by green tea extract in rat," Japanese Journal of Cancer Research, vol. 86, no. 11, pp. 1106-1111, 1995.

[11] M. Xu, A. C. Bailey, J. F. Hernaez, C. R. Taoka, H. A. J. Schut, and R. H. Dashwood, "Protection by green tea, black tea, and indole3-carbinol against 2-amino-3-methylimidazo[4,5-f] quinolineinduced DNA adducts and colonic aberrant crypts in the F344 rat," Carcinogenesis, vol. 17, no. 7, pp. 1429-1434, 1996.

[12] IACR, International Agency of Research on Cancer: Monograph on the Evaluation of Carcinogenesis Risk To Humans, Chromium, Nickel and Welding, Lyon, France, 1990.

[13] EPA (US Environmental Protection Agency), "Toxicological review of hexavalent chromium," CAS 18540-29-9, Washington, DC, USA, 2010.

[14] J. Singh, D. L. Carlisle, D. E. Pritchard, and S. R. Patierno, "Chromium-induced genotoxicity and apoptosis: relationship to chromium carcinogenesis (review)," Oncology Reports, vol. 5, no. 6, pp. 1307-1318, 1998.

[15] T. J. O’Brien, S. Ceryak, and S. R. Patierno, "Complexities of chromium carcinogenesis: role of cellular response, repair and recovery mechanisms," Mutation Research, vol. 533, no. 1-2, pp. 3-36, 2003.

[16] T.-C. Tsou, C.-L. Chen, T.-Y. Liu, and J.-L. Yang, "Induction of 8hydroxydeoxyguanosine in DNA by chromium(III) plus hydrogen peroxide and its prevention by scavengers," Carcinogenesis, vol. 17, no. 1, pp. 103-108, 1996.

[17] S. E. Maeng, H. W. Chung, I. J. Yu et al., "Changes of 8-OH-dG levels in DNA and its base excision repair activity in rat lungs after inhalation exposure to hexavalent chromium," Mutation Research, vol. 539, pp. 109-116, 2003.

[18] X. Shi, Y. Mao, A. D. Knapton et al., "Reaction of Cr(VI) with ascorbate and hydrogen peroxide generates hydroxyl radicals and causes DNA damage: role of a Cr(IV)-mediated Fenton-like reaction," Carcinogenesis, vol. 15, no. 11, pp. 2475-2478, 1994.

[19] X. Shi and N. S. Dalal, "The role of superoxide radical in chromium(VI)-generated hydroxyl radical: the Cr(VI) HaberWeiss cycle," Archives of Biochemistry and Biophysics, vol. 292, no. 1, pp. 323-327, 1992.

[20] A. K. Patlolla, C. Barnes, D. Hackett, and P. B. Tchounwou, "Potassium dichromate induced cytotoxicity, genotoxicity and oxidative stress in human liver carcinoma (HepG2) cells," International Journal of Environmental Research and Public Health, vol. 6, no. 2, pp. 643-653, 2009.

[21] M. Ding and X. Shi, "Molecular mechanisms of Cr(VI)-induced carcinogenesis," Molecular and Cellular Biochemistry, vol. 234235, pp. 293-300, 2002.

[22] E. White, "Life, death, and the pursuit of apoptosis," Genes and Development, vol. 10, no. 1, pp. 1-15, 1996.

[23] A. K. Taraphdar, M. Roy, and R. K. Bhattacharya, "Natural products as inducers of apoptosis: implication for cancer therapy and prevention," Current Science, vol. 80, no. 11, pp. 1387-1396, 2001.

[24] M. Roy, S. Chakrabarty, D. Sinha, R. K. Bhattacharya, and M. Siddiqi, "Anticlastogenic, antigenotoxic and apoptotic activity of epigallocatechin gallate: a green tea polyphenol," Mutation Research, vol. 523-524, pp. 33-41, 2003.

[25] M. C. García-Rodríguez, R. E. Vilches-Larrea, T. NicolásMendez, and M. A. Altamirano-Lozano, "El té verde en la quimioprevención in vivo del daño genotóxico inducido por metales cancerígenos (cromo[VI])," Nutrición Hospitalaria, vol. 27, no. 4, pp. 1188-1196, 2012. 
[26] D. Komes, D. Horžic, A. Belšcak, G. K. Kovacevic, and I. Vulic, "Green tea preparation and its influence on the content of bioactive compounds," Food Research International, vol. 43, pp. 167-176, 2010.

[27] T. Neckvapil, V. Kopriva, V. Boudny, M. Hostovsky, P. Dvorak, and L. Malota, "Decrease in the antioxidant capacity in beverages containing tea extracts during storage," Scientific World Journal, vol. 2012, Article ID 361698, 5 pages, 2012.

[28] V. K. Ananingsih, A. Sharma, and W. Zhou, "Green tea catechins during food processing and storage: a review on stability and detection," Food Research International, vol. 50, pp. 469-479, 2013.

[29] Y. Sakamoto, H. Mikuriya, K. Tayama et al., "Goitrogenic effects of green tea extract catechins by dietary administration in rats," Archives of Toxicology, vol. 75, no. 10, pp. 591-596, 2001.

[30] M. C. García-Rodríguez, V. López-Santiago, and M. Altamirano-Lozano, "Effect of chlorophyllin on chromium trioxide-induced micronuclei in polychromatic erythrocytes in mouse peripheral blood," Mutation Research, vol. 496, no. 1-2, pp. 145-151, 2001.

[31] J. A. Heddle, M. Hite, and B. Kirkhart, "The induction of micronuclei as a measure of genotoxicity. A report of the U.S. Environmental Protection Agency gene-tox program," Mutation Research, vol. 123, no. 1, pp. 61-118, 1983.

[32] M. Aida, Y. Birukawa, N. Hachiya et al., "Protocol recommended by the CSGMT/JEMS.MMS for the short-term mouse peripheral blood micronucleus test," Mutagenesis, vol. 10, no. 3 , pp. 153-159, 1995.

[33] A. J. McGahon, S. J. Martin, R. P. Bissonnette et al., "Chapter 9 the end of the (cell) line: methods for the study of apoptosis In Vitro," Methods in Cell Biology, vol. 46, pp. 153-185, 1995.

[34] OECD, Guideline for Testing of Chemicals. No. 474: Mammalian Erythrocyte Micronucleus Test, 1997.

[35] FDA, "Food and Drug Administration: Guidelines for reproduction studies for safety evaluations of drugs for human use," Silver Spring, Md, USA, 2000 http://www.oecd.org/env/ehs/ testing/healtheffects.htm.

[36] M. Hayashi, T. Morita, Y. Kodama, T. Sofuni, and M. Ishidate Jr., "The micronucleus assay with mouse peripheral blood reticulocytes using acridine orange-coated slides," Mutation Research, vol. 245, no. 4, pp. 245-249, 1990.

[37] I.-D. Adler, J. Bootman, J. Favor et al., "Recommendations for statistical designs of in vivo mutagenicity tests with regard to subsequent statistical analysis," Mutation Research, vol. 417, no. 1, pp. 19-30, 1998.

[38] M. C. García-Rodríguez and M. Altamirano-Lozano, "Study of effects chlorophyllin on genotoxic and teratogenic damage induced by chromium (VI)," Environmental Molecular Mutagenesis, vol. 47, no. 6, article 460, 2006.

[39] R. A. Isbrucker, J. Bausch, J. A. Edwards, and E. Wolz, "Safety studies on epigallocatechin gallate (EGCG) preparations. Part 1: genotoxicity," Food and Chemical Toxicology, vol. 44, no. 5, pp. 626-635, 2006

[40] Y.-W. Hsu, C.-F. Tsai, W.-K. Chen, C.-F. Huang, and C.-C. Yen, "A subacute toxicity evaluation of green tea (Camellia sinensis) extract in mice," Food and Chemical Toxicology, vol. 49, no. 10, pp. 2624-2630, 2011.
[41] S. A. Aherne and N. M. O’Brien, "Mechanism of protection by the flavonoids, quercetin and rutin, against tertbutylhydroperoxide- and menadione-induced DNA single strand breaks in Caco-2 cells," Free Radical Biology and Medicine, vol. 29, no. 6, pp. 507-514, 2000.

[42] S. Caillet, H. Yu, S. Lessard, G. Lamoureux, D. Ajdukovic, and M. Lacroix, "Fenton reaction applied for screening natural antioxidants," Food Chemistry, vol. 100, no. 2, pp. 542-552, 2007.

[43] D. L. Carlisle, D. E. Pritchard, J. Singh, and S. R. Patierno, "Chromium (VI) induces p53-dependent apoptosis in diploid human lung and mouse dermal fibroblasts," Molecular Carcinogenesis, vol. 28, pp. 111-118, 2000.

[44] D. Bagchi, M. Bagchi, and S. J. Stohs, "Chromium (VI)-induced oxidative stress, apoptotic cell death and modulation of p53 tumor suppressor gene," Molecular and Cellular Biochemistry, vol. 222, no. 1-2, pp. 149-158, 2001.

[45] Y. Hayashi, T. Kondo, Q.-L. Zhao et al., "Signal transduction of p53-independent apoptotic pathway induced by hexavalent chromium in U937 cells," Toxicology and Applied Pharmacology, vol. 197, no. 2, pp. 96-106, 2004.

[46] J. Ye, S. Wang, S. S. Leonard et al., "Role of reactive oxygen species and p53 in chromium(VI)-induced apoptosis," Journal of Biological Chemistry, vol. 274, no. 49, pp. 34974-34980, 1999.

[47] S. Okabe, M. Suganuma, M. Hayashi, E. Sueoka, A. Komori, and H. Fujiki, "Mechanisms of growth inhibition of human lung cancer cell line, PC-9, by tea polyphenols," Japanese Journal of Cancer Research, vol. 88, no. 7, pp. 639-643, 1997.

[48] H. Fujiki, M. Suganuma, S. Okabe et al., "Cancer inhibition by green tea," Mutation Research, vol. 402, no. 1-2, pp. 307-310, 1998.

[49] H. Hibasami, Y. Achiwa, T. Fujikawa, and T. Komiya, "Induction of programmed cell death (Apoptosis) in human lymphoid leukemia cells by catechin compounds," Anticancer Research, vol. 16, no. 4 A, pp. 1943-1946, 1996.

[50] N. Ahmad, D. K. Feyes, A.-L. Nieminen, R. Agarwal, and H. Mukhtar, "Green tea constituent epigallocatechin-3-gallate and induction of apoptosis and cell cycle arrest in human carcinoma cells," Journal of the National Cancer Institute, vol. 89, no. 24, pp. 1881-1886, 1997.

[51] Y. Gao, W. Li, B. Li, Y. C. Chen, and Y. Tu, "Enhancement of (-)-epigallocatechin-3-gallate and theaflavin-3-3'-digallate induced apoptosis by ascorbic acid in human lung adenocarcinoma SPC-A-1 cells and esophageal carcinoma Eca-109 cells via MAPK pathways," Biochemical and Biophysical Research Communications, vol. 438, pp. 370-374, 2013.

[52] M. Suganuma, S. Okabe, Y. Kai, N. Sueoka, E. Sueoka, and H. Fujiki, "Synergistic effects of (-)-epigallocatechin gallate with (-)-epicatechin, sulindac, or tamoxifen on cancer-preventive activity in the human lung cancer cell line PC-9," Cancer Research, vol. 59, no. 1, pp. 44-47, 1999.

[53] M. Singh, K. Bhui, R. Singh, and Y. Shukla, "Tea polyphenols enhance cisplatin chemosensitivity in cervical cancer cells via induction of apoptosis," Life Sciences, vol. 93, pp. 7-16, 2013. 


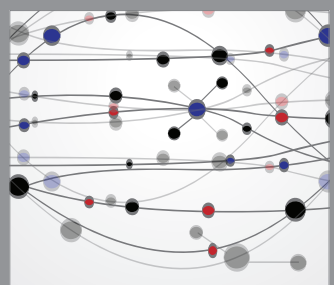

The Scientific World Journal
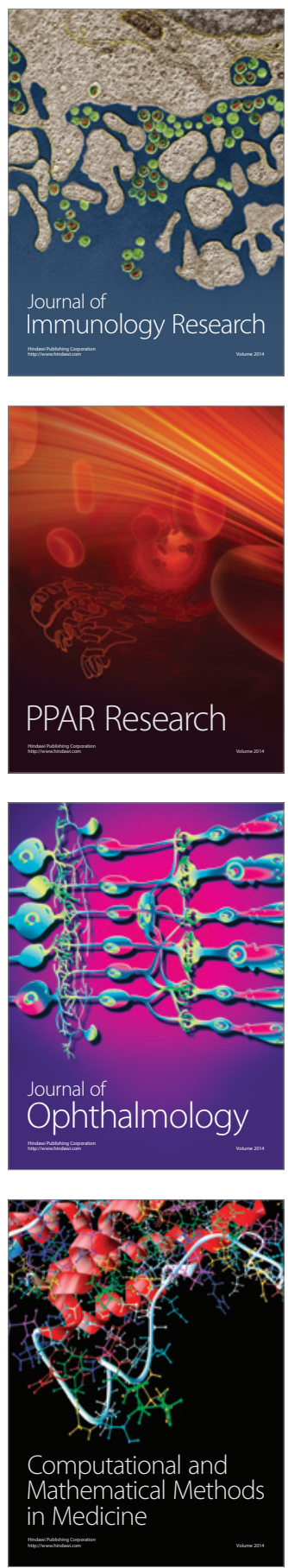

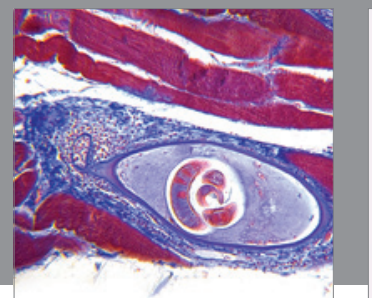

Gastroenterology

Research and Practice
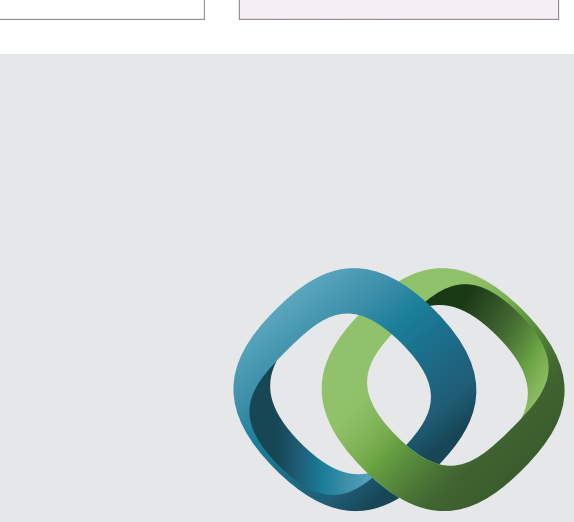

\section{Hindawi}

Submit your manuscripts at

http://www.hindawi.com
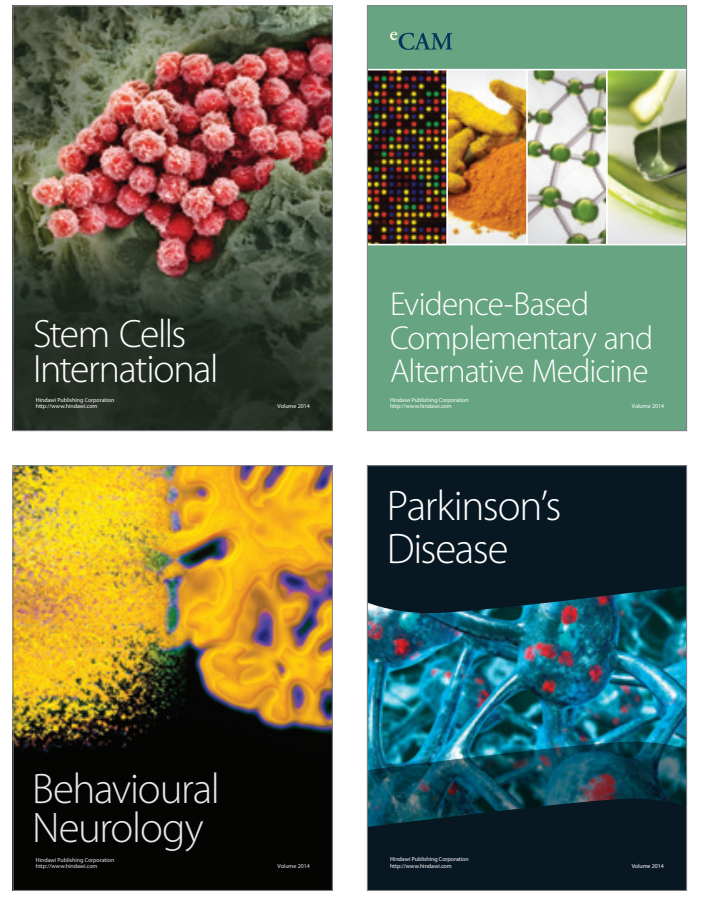
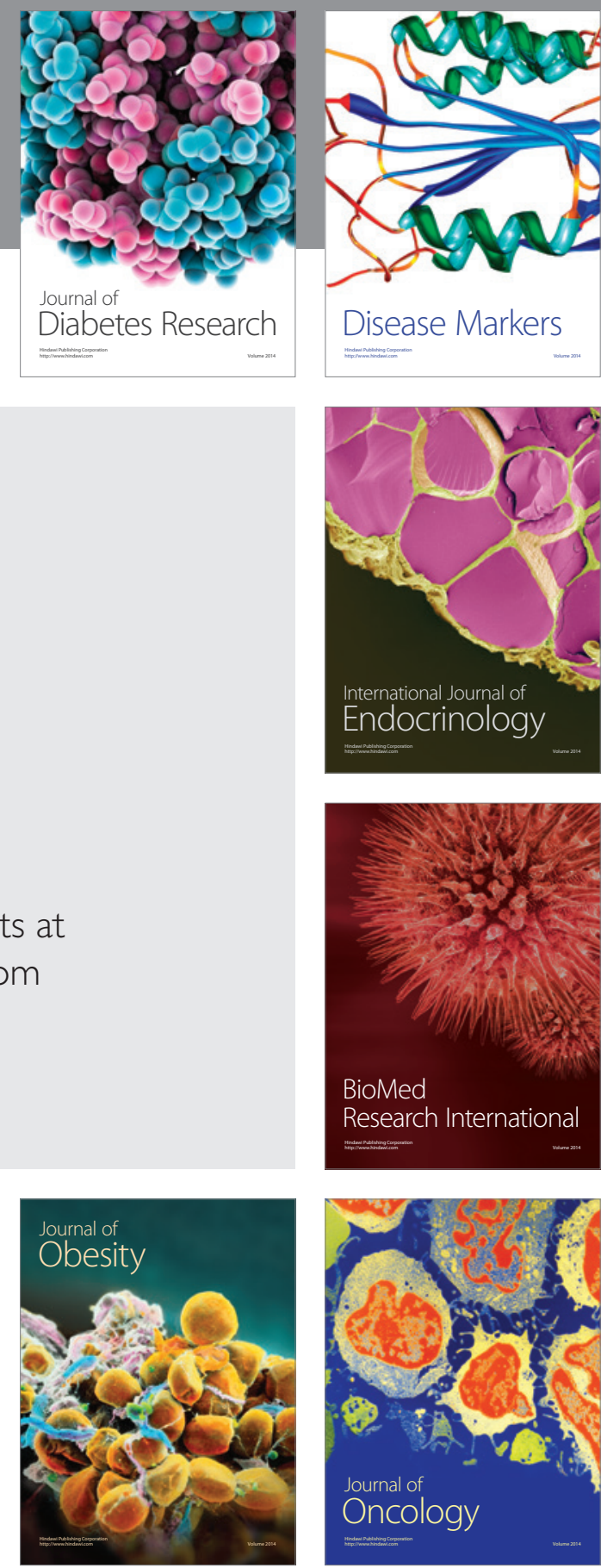

Disease Markers
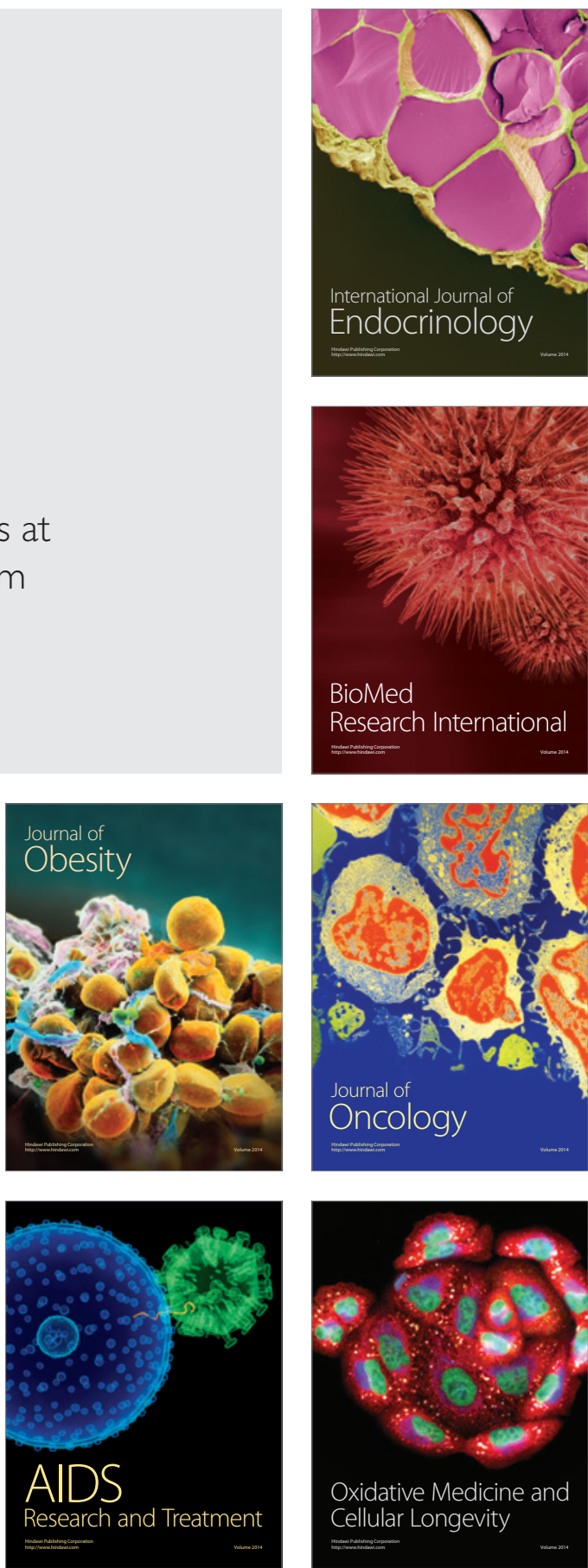